\title{
KEBERPIHAKAN PENDIDKAN JASMANI, OLAH RAGA DALAM PERSPEKTIF GENDER
}

\author{
Siti Divinubun \\ Fakultas Ilmu Keguruan \& Ilmu Pendidikan Universitas Patimura \\ sitidivin@gmail.com
}

\begin{abstract}
ABSTRAK
Pendidikan jasmani pada hakikatnya adalah sebuah proses pendidikan yang memanfaatkan aktivitas fisik untuk menghasilkan perubahan holistik dalam kualitas individu, baik dalam hal fisik, mental, serta emosional. Keberpihakan Pendidikan jasmani memperlakukan individu sebagai sebuah kesatuan utuh, mahluk total, daripada hanya menganggapnya sebagai seseorang yang terpisah kualitas fisik danmentalnya, dan Gender merupakan Hal lain yang perlu dipahami dan dilakukan dengan kajian untuk dimegerti perbedaan konsep gender dan seks (jenis kelamin). Kesalahan dalam memahami makna gender merupakan salah satu faktor yang menyebabkan sikap menentang atau sulit bisa menerima analisis gender dalam memcahkan masalah ketidakadilan sosial.
\end{abstract}

Kata kunci : Pendidikan jasmani,olahraga,dan gender

\section{PENDAHULUAN}

Pelaksanaan pembangunan nasional di bidang pendidikan adalah usaha mencerdaskan bangsa dalam rangka meningkatkan kualitas manusia Indonesia dan mewujudkan manusia yang maju, adil dan makmur. Untuk mewujudkan tujuan nasional di bidang pendidikan tersebut pemerintah mengupayakan perluasan dan pemerataan kesempatan memperoleh pendidikan yang bermutu tinggi bagi seluruh rakyat Indonesia menuju terciptanya manusia Indonesia yang berkualitas tinggi dengan peningkatan anggaran pendidikan secara berarti (GBHN 2004: 74).Aspek yang harus diperhatikan dalam usaha peningkatan pendidikan jasmani ialah satunya adalah proses belajar yang panjang (proses), karena itu lingkungan belajar sangat mengatur secara sesakma untuk meningkatkan pertumbuhan dan perkembangan seluruh ranah, jasmani, psikomotor, kognitif, dan efektif setiap siswa. (Direktorat Jendral Pendidikan Dasar Menengah, 2003: 2).

Sementara Olahraga mempunyai manfaat yang terukur bagi kesehatan, memberi kegembiraan, pergaulan (friendship) dan kepuasan bagi para Pelakunya. Manfaat aktivitas fisik untuk mengatur berat badan, membangkitkan rasa percaya diri, memelihara koordinasi motorik, kesehatan dan kebugaran kardiovaskular serta integritas tulang, nyata lebih besar bagi wanita dari pada bagi pria. Oleh karena itu, olahraga bagi wanita harus dipromosikan dan didorong pelaksanaannya dengan kuat. Dalam budaya modern, wanita secara berangsur mendapatkan persamaan hak dan kewajiban dengan pria. Dari pengucilan total pada jaman olympiade kuno, lalu hanya menjadi penonton dalam jaman awal olympiade modern, ternyata dalam perkembangan selanjutnya kekuatan, bakat, keberanian berkompetisi para wanita menjadi semakin diakui dan memenuhi semua tingkatan olahraga. Masalah pengaruh keberpihakan perempuan pada wilayahwilayah explorasi diri yang dianggapa berlebihan, sehingga Agaknya apa yang disebut kodrat (Menstruasi,hamil,dan melahirkan), sekarang dianggap sebagai bagian yang sangap penting (asset), bukannya kerugian dalam olahraga. Demikian pula, keibuan terbukti tidak mengurangi kemampuan jasmani seorang ibu, sedangkan olahraga yang dilaksanakan secara tepat bahkan terbukti dapat meningkatkan kesehatan ibu selama hamil dan melahirkan. Dengan demikian tantangan bagi pendidikan jasmani dan olahraga adalah meyakinkan bahwa wanita dapat mencapai puncak penampilan fisiknya, sambil terus menikmati kesehatannya dengan baik sebagai seorang perempuan yang sempurna di mata Tuhan dan manusia.

\section{KAJIAN PUSTAKA \& PEMBAHASAN}

\section{Hakekat pendidikan jasmani}

Pada hakekatnya pendidikan jasmani adalah proses pendidikan yang melibatkan interaksi antara peserta didik dengan lingkungannya, yang dikelola melalui aktivitas jasmani 
secara sistematik menuju pembentukan manusia seutuhnya. Aktivitas jasmani diartikan sebagai kegiatan peserta didik untuk meningkatkan keterampilan motorik dan nilainilai fungsional yang mencakup, kognitif, afektif, dan sosial.

Bila tujuan pendidikan nasional tersebut dianalisis, terdapat empat tujuan pokok yang dipentingkan dalam proses pendidikan, yaitu: manusia Indonesia yang bermoral dan berbudi pekerti luhur, sehat jasmani dan rohaninya, memiliki pengetahuan dan keterampilan, dan memiliki kepedulian sosial yang tinggi kemudian, Jika direnungkan, maka tujuan pendidikan jasmani pun sebenarnya selaras dengan tujuan pendidikan nasional. Oleh karena itu tidak berlebihan jika pendidikan jasmani berperan penting dalam menunjang tujuan pendidikan nasional tersebut, sebagaimana arti dari pendidikan jasmani itu sendiri. Salah satu definisi pendidikan jasmani (Cholik dan Lutan, 1997) adalah sebagai berikut: " Pendidikan Jasmani adalah suatu proses yang dilakukan secara sadar dan sistematik melalui berbagai kegiatan jasmani untuk memperoleh pertumbuhan jasmani, kesehatan, dan kebugaran jasmani, kemampuan dan keterampilan, kecerdasan dan perkembangan watak serta kepribadian yang harmonis dalam rangka membentuk manusia Indonesia seutuhnya yang berkualitas berdasarkan Pancasila".

Berdasarkan Keputusan Menteri Pendidikan dan Kebudayaan No. 413/U/1987 berbunyi: ".Pendidikan jasmani merupakan bagian integral dari pendidikan secara keseluruhan melalui berbagai kegiatan jasmani yang bertujuan mengembangkan individu secara neuromuskuler, intelektual dan emosional". Sedang Unesco dalam International Charter of Physical Education memberikan batasan Pendidikan Jasmani sebagai berikut: "Pendidikan Jasmani adalah suatu proses pendidikan seseorang sebagai individu maupun sebagai anggota masyarakat yang dilakukan secara sadar dan sistematik melalui berbagai kegiatan jasmani dalam rangka memperoleh peningkatan kemampuan dan ketrampilan jasmani, pertumbuhan kecerdasan dan pembentukan watak" Oleh karena itu pendidikan jasmani hendaknya diarahkan untuk membantu siswa dalam peningkatan kebugaran jasmani dan kesehatan melalui pengenalan dan penanaman sikap positif serta kemampuan gerak dasar dan berbagai aktifitas fisik / jasmani, agar dapat:

1. tercapainya pertumbuhan dan perkembangan jasmani khususnya tinggi badan dan berat badan secara harmonis.

2. terbentuknya sikap dan perilaku disiplin, jujur, kerjasama, mengikuti peraturan dan ketentuan yang berlaku.

3. menyenangi aktivitas jasmani yang dapat dipakai untuk mengisi waktu serta kebiasaan hidup sehat.

Oleh sebab itu Pendidikan jasmani merupakan suatu proses seseorang sebagai individu maupun anggota masyarakat yang dilakukan secara sadar dan sistematik melalui berbagai kegiatan dalam rangka memperoleh kemampuan dan keterampilan jasmani, pertumbuhan, kecerdasan, dan pembentukan watak. Pendidikan jasmani pada hakikatnya adalah proses pendidikan yang memanfaatkan aktivitas fisik untuk menghasilkan perubahan holistik dalam kualitas individu, baik dalam hal fisik, mental, serta emosional, kemudian Setiap hal yang mempengaruhi perilaku dan kepribadian seseorang dapat disebut pendidikan. karena mencakup aspek jasmaniah (keterampilan, kesehatan, kebugaran jasmani), intelektual (pengetahuan dan penalaran, serta pembuatan keputusan), dan sifat-sifat afektif yang mencakup aspek emosional, sosial, moral, dan spiritual.

\section{Pembahasan}

Gender merupakan sebuah perlakuan membedakan laki-laki dan perempuan dalam pandangan norma dan budaya yang ada di sebuah masyarakat. Tidak ada yang salah dengan gender. Istilah gender hanyalah sebuah istilah yang sangat ditentukan oleh kapan dan dimana laki-laki serta perempuan tersebut tinggal dan dibedakan. Keadaan dan situasi tersebut menentukan pandangan masyarakat atas status laki-laki dan perempuan. Keberadaan tempat dan waktu status individu merupakan penentu utama dalam melihat peran laki-laki dan perempuan yang dianggap pantas dan layak dalam kehidupan di masyarakat. Dalam teori sosial makro tentang gender, penempatan perbedaan jenis kelamin berskala luas. Adapun teori yang mendukung adalah teori fungsionalisme, teori konflik analitis dan teori sistem dunia neo-marxism. Dari ketiga teori tersebut, akhirnya memperoleh satu kesepakatan bahwa tempat utama bagi 
perempuan adalah sebuah tempat yang khusus yaitu keluarga (rumah tangga). Meskipun perempuan menjadi pelaku dalam kegiatan ekonomi pasar, namun pada akhirnya akan beralih fungsi sebagai upaya untuk memahami fungsi keluarga.Selain itu, ketiga teori tersebut juga berkonsentrasi untuk menerangkan stratifikasi gender yang pada umumnya masih terdapat kerugian pada posisi perempuan (George Ritzer dan Douglas J. Goodman, 2005 : 408- 411).

Perempuan di Indonesia menempati posisi-posisi strategis sebagai guru, manajer perusahaan, dokter dan lain sebagainya. Selain tugas dan kewajiban perempuan untuk berperan secara maksimal di ruang publik, perempuan juga memerankan diri sebagai ibu yang mengurus anak dan rumah tangganya. Dalam teori sosial mikro, terjadi perdebatan tajam terkait interaksi sosial dan perbedaan gender.Pembahasan dalam teori ini didukung oleh teori interaksionisme simbolik dan etnometodologi. Baik interaksionisme simbolik maupun etnometodologi, sama-sama menghargai dan menerima sehingga gender dianggap hal penting yang perlu dilakukan dalam kajian gender adalah memahami perbedaan konsep gender dan seks (jenis kelamin). Kesalahan dalam memahami makna gender merupakan salah satu faktor yang menyebabkan sikap menentang atau sulit bisa menerima analisis gender dalam memcahkan masalah ketidakadilan sosial. Kemudian dijelaskan oleh Mansour Faqih, sex berarti jenis kelamin yang merupakan penyifatan atau pembagian jenis kelamin yang ditentukan secara biologis yang melekat pada jenis kelamin tertentu. Perbedaan anatomi biologis ini tidak dapat diubah dan bersifat menetap, kodrat dan tidak dapat ditukar. Oleh karena itu perbedaan tersebut berlaku sepanjang zaman dan dimana saja.

\section{Hubungan Penjas degan gender}

1. Komponen Kebugaran Jasmani

Kebugaran jasmani sangat penting dalam menunjang aktifitas kehidupan sehari-hari, akan tetapi nilai kebugaran jasmani tiap-tiap orang berbeda-beda sesuai dengan tugas/profesi masing-masing. Kebugaran jasmani terdiri dari komponen-komponen yang dikelompokkan menjadi kelompok yang berhubungan dengan kesehatan (Health Related Physical Fitness) dan kelompok yang berhubungan dengan ketrampilan (Skill Related Physical Fitness). Hal ini hanya dijelaskan komponen kebugaran jasmani yang berkaitan dengan kesehatan. Komponen Kebugaran Jasmani yang antara lain :

1. Komposisi tubuh

Adalah persentase (\%) lemak dari berat badan total dan Indeks Massa Tubuh (IMT). Lemak cepat meningkat setelah berumur 30 tahun dan cenderung menurun setelah berumur 60 tahun.Memberi bentuk tubuh. Pengukuran : Skinfold callipers, IMT, IMT $=($ Berat Badan Dalam kg : Tinggi Badan Dalam M2) Obesitas pada anak-anak disebabkan oleh : hipeplasi dan hipertropi sel adiposit serta input berlebihan. Obesitas pada orang dewasa oleh : hiperplasi dan hipertropi sel adiposit serta output yang kurang.

\section{Kelenturan/fleksibilitas tubuh}

Adalah luas bidang gerak yang maksimal pada persendian, tanpa dipengaruhi oleh suatu paksaan atau tekanan. Dipengaruhi oleh: Jenis sendi; Struktur tulang; Jaringan sekitar sendi, otot, tendon dan ligamen. Wanita (terutama ibu hamil) lebih lentur dari laki-laki. Anak-anak lebih besar dari orang dewasa. Puncak kelenturan terjadi pada akhir masa pubertas. Penting pada setiap gerak tubuh karena meningkatkan efisiensi kerja otot. Dapat mengurangi cedera (orang yang kelenturannya tidak baik cenderung mudah mengalami cedera). Pengukuran: Duduk tegak depan (Sit and reachTest) Flexometer.

\section{Kekuatan Otot}

Adalah kontraksi maksimal yang dihasilkan otot, merupakankemampuan untuk membangkitkan tegangan terhadap suatutahanan. Laki-laki kira-kira 25\% lebih besar dari wanita (Testoteronmerupakan anabolik steroid).Diukur dengan dinamometer.

\section{Daya tahan jantung paru}

Kemampuan jantung, paru dan pembuluh darah untukberfungsi secara optimal pada waktu kerja dalam mengambilO2 secara maksimal (VO2 maks) dan menyalurkannya keseluruh tubuh terutama jaringan aktif sehingga dapatdigunakan untuk proses metabolisme tubuh. Kemampuan otot-otot besar untuk melakukan pekerjaan cukup berat dalam waktu lama secara terus menerus. Merupakan komponen kebugaran jasmani terpenting. Pengukuran : test lari 2,4 Km (12 menit), Bangku Harvard test,Ergocycles test.

5. Daya tahan otot, merupakan kemampuan untuk kontraksi sub maksimal secaraberulang- 
ulang atau untuk berkontraksi terus menerus dalamsuatu waktu tertentu. Mengatasi kelelahan. Pengukuran : Push up test, Sit up test.

Selama ini, ada anggapan di kalangan masyarakat luas bahwa anak perempuan tidak perlu melakukan olahraga.Padahal, sejumlah penelitian yang dilakukan oleh kalangan ahli nutrisi dan kesehatan, telah membuktikan bahwa anak perempuan juga mesti melakukan olahraga karena memiliki banyak manfaat untuk dirinya.Seperti dilansir (magforwomen), berikut lima alasan anak perempuan harus berolahraga karena akan :

1. Meningkatkan Kepercayaan Diri

Dengan berolahraga, membuat anak perempuan mengetahui bahwa dirinya bisa berlatih, meningkatkan kemampuan dan meraih target. Selain itu, juga mempertahankan bentuk tubuh, berat badab dan berteman dengan banyak orang.

\section{Belajar Kerjasama Mencapai Target}

Olahraga mengajarkan kerjasama dengan rekan satu tim untuk meraih target ataupun kemenangan. Dengan begitu, anak perempuan akan mempelajari cara menjadi sukses, baik dalam karir maupun kehidupan.

\section{Lebih Pandai di Sekolah}

Berdasar sejumlah penelitian, olahraga terbukti mampu meningkatkan kemampuan belajar, mengingat dan berkonsentrasi.

\section{Mencegah Depresi}

Kegiatan berolahraga diketahui mampu menekan stres dan memicu hormon dalam otak untuk melepaskan sinyal rasa bahagia, sekaligus memperbaiki mood seseorang.

\section{Baik untuk Kesehatan}

Olahraga selain mampu menjauhkan anak perempuan dari kecendrungan negatif (merokok, narkoba dan lain-lain), juga bisa menghindarkan diri terhadap risiko kanker payudara dan osteoporosis. Mengapa Anda berolahraga ? jawabannya pasti untuk menjaga kesehatan tubuh, bersenang-senang dan menghilangkan rasa penat.

Namun ada alasan lain mengapa kita harus berolahraga, khususnya bagi anak-anak perempuan. Berdasarkan the Women Sport Foundation, anak-anak perempuan yang melakukan berolahraga, tidak hanya akan mendapatkan keuntungan dalam menjaga tubuhnya selalu fit, namun terdapat lima alasan lainnya mengapa harus membiasakan anakanak perempuan Anda berolahraga, yaitu :

1. Anak perempuan yang berolahraga akan lebih baik dalam menghadapi pelajaran di sekolah. Anda mungkin berpikir menjadi seorang atlet akan menghabiskan atau mengganggu waktu belajarnya. Tetapi sebuah penelitian menunjukkan anak-anak perempuan yang melakukan kegiatan olahraga, lebih baik dalam menghadapi pelajaran di sekolahnya. Dengan berolahraga akan mengingkatkan kegiatan belajar, ingatan, dan konsentrasi sehingga akan memberikan keuntungan bagi anak perempuan untuk aktif di kelas.

2. Mampu bekerja dalam kelompok dan memiliki keahlian untuk mencapai tujuannya. Olahraga mengajarkan nilai-nilai berharga dalam kehidupan. Dalam olahraga Anda akan mempelajari bagaimana bekerjasama yang baik untuk mendapatkan kesuksesan, bersama pelatih dan teman satu kelompok. Keahlian ini akan sangat membantu dalam dunia kerja dan kehidupan keluarga.

3. Berolahraga baik untuk kesehatan anak perempuan. Selain akan mendapatkan tubuh yang sehat dan mampu mengontrol berat badan, kemungkinan besar seseorang yang rajin berolahraga tidak akan tumbuh menjadi seorang perokok. Keuntungan lainnya, mereka akan terhindar dari penyakit kanker payudara atau osteoporosis.

4. Dengan olahraga mampu meningkatkan rasa percaya diri. Olahraga dapat membangkitkan rasa percaya diri karena ia akan mengetahui bagaimana cara untuk mempraktekkan, memperbaiki, dan meraih tujuan yang diinginkannya. Olahraga juga dapat membantu menjaga bentuk tubuh, berat badannya dan menambah teman baru.

5. Olahraga mampu menghilangkan berbagai tekanan atau masalah.

Olahraga mampu mengurangi stres dan mendatangkan rasa bahagia. Hal ini karena saat berolahraga, otak akan melepaskan zat-zat kimia yang akan meningkatkan mood seseorang. Seorang teman juga mampu meningkatkan mood Anda, dengan berada dalam sebuah tim akan meningkatkan ikatan kuat antar teman. Kemudian pengaruh lainnya terhadap,

\section{Olahraga Dan Wanita}

Menurut (Boston Marton, 2003) wanita melakukan olahraga mempunyai kelebihan dibandingkan pria, ini disesbabkan karena 
wanita mempunyai berat badan yang ringan dibandingkan pria, adanya lemak lebih banyak pada tubuh wanita merupakan cadangan energy yang lebih besar, kemampuan berbeda enzim metabolisme lemak lebih besar dari pada pria, sedangkan kerugian pada wanita hemoglobin menjadi menurun secara dratis, selain itu juga karena adanya mentsruasi, makanya para wanita dianjurkan makan makanan yang mengandung zat besi tinggi. Dan apabila tubuh tidak beraktifitas maka kerja paru- paru menjadi tidak lebih efesien masing melemah, keluturan pembuluh darah berkembang sehingga tubuh menjadi lemah, latihan olahraga untuk kesegaran jasmani yang sesuai dengan kebutuhan setiap orang dan olahraga yang dilakukan memberikan manfaat diantaranya peningkatan :

- paru - paru

- Peningkatan jumlah ukuran pembuluh pembuluh darah

- Peningkatan volume darah

- Meningkatan tekanan darah tinggi.

a. Perbedaan fisik pria dan wanita

Banyak penelitian-penelitian terhadap kapasitas fisik wanita dilakukan pada subjek yang kurang terlatih, sehingga menunjukkan kapasitas kerja yang relatif buruk, dan ini dimasa lalu menjadi pembatas bagi wanita untuk berpartisipasi dalam olahraga. Tetapi wanita sungguh dapat dilatih dan perbedaan parameter fisiologik antara wanita dan pria yang terlatih menjadi lebih kecil dari pada orang kebanyakan. Fakta pada orang kebanyakan inilah yang dijadikan petanda rendahnya tingkat keterlatihan pada „kebanyakan,, wanita. Latihan kekuatan yang terpimpin dan sistematis merupakan kegiatan yang menyehatkan dan menggembirakan anakanak wanita, karena di balik latihan itu tersimpan potensi untuk meningkatkan densitas tulang sehingga merupakan pencegahan osteoporosis di kemudian hari.

Di samping itu dengan latihan kekuatan yang sistematik, wanita dapat meningkatkan diameter serabut otot dan massa total ototnya, tetapi tidak dapat menyamai apa yang dicapai pria oleh karena kadar testosteronnya yang relatif lebih rendah. Pada awalnya peningkatan kekuatan otot dapat terjadi tanpa meningkatnya ukuran otot, dan hal ini disebabkan oleh karena membaiknya pengerahan satuan neuromuskular sebagai hasil pelatihan. Kandungan lemak yang pada umumnya lebih tinggi pada wanita tidak menghasilkan perbaikan olahdaya (metabolisme) lemak pada event olahraga daya-tahan misalnya maraton, sebagai-mana yang dahulu diyakini. Lemak tubuh yang tinggi pada wanita menjadi hambatan bagi kegiatan fisik yang bersifat weight bearing (mengusung beban/ berat badan), tetapi hal itu meningkatkan daya apung pada renang, dan menjadi faktor keunggulan penampilan perenang-perenang "jarak ultra jauh" wanita (Sharp 1984).

Kandungan lemak tubuh dengan latihan kekuatan akan menurun yang berarti membaiknya rasio BB tanpa lemak terhadap BB dengan lemak yang merupakan respons terhadap latihan. Banyak atlet daya-tahan wanita mempunyai kandungan lemak yang nyata lebih sedikit dari pada atlet power pria. Untuk wanita, hasil yang diharapkan dengan latihan kekuatan adalah menghasilkan tubuh yang lebih ramping dan lebih sehat yang akan membuatnya menjadi lebih tahan terhadap cedera olahraga. Pria dan wanita dapat kita bedakan dari segi fisik, baik secara anatomismaupun secara fisiologis (fungsi tubuh). Perbedaan anatomi ini menyebabkan pria lebih mampu melakukan aktivitas jasmani dan olahraga yang memerlukan kekuatan dan dimensi lain yang lebih besar (Kartinah, Komariah, Giriwijoyo,2006: 177). Secara fisik, pria dewasa rata-rata $7-10 \%$ lebih besar daripadawanita. Perbedaan ukuran itu sangat kecil terlihat pada anak-anak sampai usiapubertas. Velle menjelaskan bahwa akivitas jasmani pria yang lebih tinggi karenapengaruh hormon di dalam otak selama perkembangan janin (Sutresna, 1999:259).

$$
\text { Pengaruh hormon testoteron }
$$
mengakibatkan pria tumbuh lebih tinggi, gelang bahuyang lebih luas, panggul lebih sempit dan tungkai lebih panjang. Sedangkanpengaruh hormon estrogen mengkibatkan wanita berkembang dengan bahu yanglebih sempit, panggul yang lebih luas relatif terhadap tinggi badannya dan"carrying angle" yang lebih besar pada sendi siku. Pada wanita terjadipenimbunan lemak selama masa pubertas, sedangkan pada pria terjadiperkembangan otot. Sehingga wanita dewasa mempunyai lemak sekitar dua kalilebih besar dari pada pria. Pria mempunyai darah yang kurang lebih satu literlebih banyak dari pada wanita. Selain itu dimensi jantung pada pria lebih besarsehingga volume sedenyut lebih besar, volume paru-paru pria lebih besar $10 \%$ dari pada wanita. Wanita mempunyai denyut nadi istirahat yang lebih sedikittinggi 
dengan Denyut Nadi Maksimal sesuai umur sama.Berbagai penelitian lebih banyak melihat bahwa wanita mempunyaikapasitas kerja yang relatif buruk, sehingga menjadi pembatas bagi wanita terlibatdalam olahraga. Tetapi pada wanita dan pria yang terlatih tidak terlihat perbedaansecara fisiologis.

Latihan kekuatan yang sistemik dapat meningkatkan diameter serabut otot dan massa total ototnya. Kandungan lemak dalam tubuh menurunsebagai respon terhadap latihan. Banyak atlit wanita dalam olahraga yangmemerlukan daya tahan mempunyai kandungan lemak yang sedikit. Lemak tubuhyang tinggi menjadi hambatan bagi kegiatan fisik yang bersifat weight bearing, tetapi meningkatkan daya apung pada renang. Pria dan wanita yang melakukan olahraga sama akan memiliki kapasitasaerobik (VO2max) dengan perbedaan yang lebih kecil dari pada sesama jeniskelamin yang melakukan olahraga berbeda. Keikutsertaan wanita dalam aktivitasjasmani dan olahraga berdampak positif pada power aerobic mereka oleh meningkatnya VO2max, Pengambilan Oksigen dan Kapasitas ventilatori. Apalagi,wanita dapat memperoleh kekuatan maksimal melalui peningkatan aktivasi otot,fleksibilitas meningkat yang berkaitan dengan peningkatan luas gerakan danbarangkali peningkatan fungsi kekebalan. Sebetulnya pria mempunyai keuntungansampai $50 \%$ dalam hal masa tubuh, volume jantung dan darah, dan hemoglobin yang tinggi. Tetapi perbedaan itu sebesar $10 \%$ apabila dinyatakan dalam satuanberat badan.

\section{KESIMPULAN \& SARAN}

Dari hasil dan pembahasan di atas dapat diketahui bahwa penjas, olahraga sangat berpihak sekali terhadap gender, hanya saja pesan yang disampaikan masih banyak perbedaan dan pengertian yang keliru termasuk media untuk mengkomunikasikan itu masih dalam banyak versi dan itupun belum ada yang belum kena pada substansi, sehingga masih banyak yang perlu diperbaiki, atau di lakukan penkajian ulang dalam rangka perbaiakan kearah yang lebih baik, padahal antara gender, wanita dan olahraga dari perspektif jenis kelamin dalam memperoleh kesempatan. Demikian seharusnya sekolah yang harus menjadi agen of change dalam memproduksi manusia yang berkelanjutan kearah masa depan, Pendidikan jasmani dan Olahraga dikembangkan tanpa menyadariperspektif gender. Namun demikian dilihat dari 21 BMP yang ditelaah, sebagian besar (16 BMP) dapat dikatakan netral dan tidak mengistimewakan salah satu gender. Selain itu presentase terbesar $(44,10 \%)$ dari semua ilustrasi yang dibuat adalah netral, atau tidak mengacu ke bentuk manusia secara eksplisit. Adapun pada laki-laki sebagai subjek dalam ilustrasi lebih mendominasi dibandingkan dengan perempuan Gambar laki-laki terutama digunakan untuk olahraga yang mengandalkan kekuatan fisik, sedangkan gambar perempuandigunakan untuk mengilustrasikan contoh olahraga yang ringan, yang membutuhkan kelenturan dan keluwesan. Berdasarkan kajian tersebut, di masa yang akan datang perlu ditekankan pentingnya prinsip kesetaraan gender, dengan cara mensosialiasikannya kembali secara sengaja dan disadari adalah mendukung kesetaraan gender, dan tidak secara salah kaprah mengikuti bias dan stereotyping yang ada di masyarakat.

\section{DAFTAR PUSTAKA}

Avgerinou, Vassiliki. Kedudukan Dan Peran Atlet Di Masyarakat. Kajian Substansi Makalah dalam Payung Sosiologi Olahraga.

Coakley. 2004. Sport in Sociaty: issues and controversies. University of Calivornia: Times Mirror/ Mosb College Pub

Giriwijoyo, Santoso. 2003. Wanita dan Olahraga. FPOK UPI Bandung.

Ibrahim, Idi Subandy. 1998. Wanita dan Media. Bandung: Rosada.

Ritzer, George dan Goodman, Douglas J . 2005. Teori Sosiologi Modern.

Perdana Media. Jakarta. Jurnal Ilmiah Spirit, ISSN, Vol II No 220011

Saraswati, Ida. 2015. Olahraga dan Makanan Sesui Golongan Darah, Jakarta: Smart Pustaka.

Susanto, Astrid S. 1985. Pengantar Sosiologi dan Perubahan Sosial. Jakarta: Bina Cipta.

Wendt, Jenice Clemons. 2000. Women In Sport. University of Houston, Houston, 